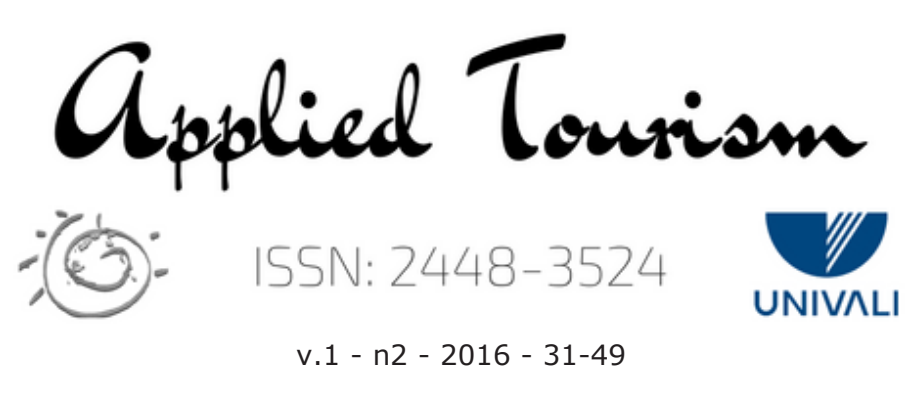

\title{
OS MOTÉIS EM CAMPO MOURÃO-PR COMO OPÇÃO PARA HOSPEDAGEM E EVENTOS
}

\section{LOVE MOTELS IN CAMPO MOURÃO (PR) AN OPTION FOR ACCOMMODATION AND EVENTS}

\author{
Aline Angeli - Graduação em Turismo e Meio Ambiente \\ Universidade Estadual do Paraná (UNESPAR). E-MAil: alineANGeli.bF@HOtMail.com
}

Recebido/Received: 16 junho/june 2015. Aprovação/Approval: 06 maio/may 2016

DOI: $10.14210 /$ at.v1n2.p31-49

\begin{abstract}
RESUMO: Esta pesquisa buscou analisar nos sete motéis da cidade de Campo Mourão-PR, as condições para hospedagem de turistas e os espaços para a realização de eventos. Para isso foram avaliados os serviços ofertados, a infraestrutura disponível, o interesse do cliente e a viabilidade do uso dos motéis para a realização de eventos e hospedagem. Como metodologia de pesquisa, foram utilizados: o levantamento histórico e legal dos motéis; a observação como cliente oculto; pesquisa através de rede social e e-mail; e, por fim, a entrevista e observação orientada. Verificou-se que, de forma geral, os serviços prestados estão dentro de um padrão aceitável pelos clientes, porém há falta de espaço apropriado para a realização de um evento nesse ambiente.
\end{abstract}

PALAVRAS-CHAVE: Motel. Eventos em Motel. Hospedagem alternativa.

\section{INTRODUÇÃO}

Este artigo aborda um tema pouco discutido nas pesquisas científicas. Trata-se
ABSTRACT: This research aims to analyze the hosting conditions and the spaces for holding events in seven love motels in the city of Campo Mourão, PR. The services provided, the available facilities, customer interest and the feasibility of using love motels for holding events and lodging were evaluated. The research methods were: historical and legal survey of motels; mystery shopping; email and social media research; and, finally, interview and guided observation. It was found that, in general, customers consider that the services are of a reasonable standard, but there is no appropriate space for holding events in that environment.

Keywords: Love Motel. Events in Love Motel. Alternative accommodation.

\section{INTRODUCTION}

This article covers a topic rarely discussed in scientific research. This is a survey to analyze the motels in the city of Campo 
de uma pesquisa para análise dos motéis da cidade de Campo Mourão, Estado do Paraná, enquanto opção para hospedagem e espaço para realização de eventos.

A cidade de Campo Mourão, segundo o Censo realizado em 2010 (IBGE, 2013) possui 87.194 habitantes. É um município predominantemente agrícola e sede da maior cooperativa brasileira e a maior cooperativa agrícola da América Latina, a Coamo Agroindustrial Cooperativa. Sendo esta, a principal empresa responsável pela circulação de turistas que visitam o município a negócios. A cidade também recebe visitantes motivados pelo turismo de lazer, estudos, tratamento de saúde, visitas a parentes e para o turismo religioso.

Outra motivação que atrai milhares de pessoas para a cidade de Campo Mourão é a Gastronomia. São três eventos de relevância: o Porco Fest, onde é servido o porco no rolete; - Costelão de São José, com a tradicional costela ao fogo de chão e a Festa Nacional do Carneiro no Buraco, que acontece sempre no mês de julho e é considerado o evento turístico gastronômico mais importante do estado, alcançando destaque nacional.

A festa do Carneiro no Buraco é visitada por mais de cem mil pessoas anualmente, recebe visitantes de todas as regiões do Brasil e para atender esses turistas, o município conta com quatorze hotéis e duas pousadas, com um total de 625 acomodações totalizando 1366 leitos (Alves, 2012). A cidade conta com sete motéis, possuindo um total de 109 acomodações ${ }^{1}$.

Os eventos a lazer, já mencionados, atraem um público maior que a capacidade de hospedagem do município. Nesses momentos, são utilizados os motéis como meio de hospedagem alternativa para suprir a necessidade dos visitantes.

Os motéis são reconhecidos como meio de hospedagem e se caracterizam pelo fracionamento de horas, além de disponibilizarem os mesmos serviços oferecidos por um hotel: alimentação, bebidas e pernoite com café da manhã.

Historicamente, os motéis eram hospedarias de beira de estrada, destinadas a viajantes. Por serem construídos distantes dos centros urbanos, passaram a assumir características luxuosas, confortáveis e muito eróticas, sendo assim utilizados por pessoas em busca de privacidade e não
Mourão, State of Paraná (PA), as an option for hosting and as a venue for events.

According to the census conducted in 2010, the population of Campo Mourão was 87,194 (IBGE 2013). It is a predominantly agricultural municipal district and headquarters of Brazil's largest cooperative and the largest agricultural cooperative in Latin America, Coamo Agroindustrial Cooperative. This company is the main responsible for the movement of tourists visiting the city for business purposes. The city also receives visitors motivated by leisure tourism, education, health care, visits to relatives and religious tourism.

Another motivation that attracts thousands of people to the city of Campo Mourão is food. There are three major events: the Pork Festival (Porco Fest), where the pig is roasted on the spit; the Big Rib of São José (Costelão de São José), with traditional rib cooked on open fire and the National Celebration of the Ram in the Hole (Festa Nacional do Carneiro no Buraco), which always takes place in July and is considered the most important gastronomic event of the state, achieving national prominence.

The National Celebration of the Ram in the Hole is attended by over one hundred thousand people annually and receives visitors from all regions of Brazil. To service these tourists, the city has fourteen hotels and two guesthouses with a total of 625 accommodation totaling 1,366 bed spaces (Alves, 2012). The city has seven love motels, in a total of 109 accommodations ${ }^{1}$.

The aforementioned leisure events attract an audience larger than the hosting capacity of the city. At such times, the motels are used as a means of alternative accommodation to meet the visitors' needs.

The love motels are recognized as a means of hosting, charging at an hourly rate, in addition to providing the same services offered by a hotel: food, drinks and overnight stay with breakfast.

Historically, the motels were roadside inns, aimed at travelers. Because they are built far from urban centers, they have assumed luxurious, comfortable and very erotic features, and thus used by people seeking privacy and not necessarily overnight stay. Today, love motels are returning to an executive character, affordable and increasingly becoming an alternative lodging for travelers. 
necessariamente pouso. Hoje os motéis voltam a ter uma característica mais executiva, com preços acessíveis e tornando-se cada vez mais um meio de hospedagem de viajantes.

Além do uso tradicional, outro segmento que vem crescendo em nível nacional, a realização de eventos em motéis como, por exemplo: aniversários, bodas, despedidas de solteiro, chá de cozinha e lançamento de livros. Diferentes, e de certa forma inusitados, os motéis oferecem essa possibilidade aos seus clientes.

Nesse sentido, o objetivo desta pesquisa foi analisar os sete motéis de Campo Mourão enquanto opção de hospedagem e espaço para a realização de eventos. Avaliando especificamente os serviços ofertados, a infraestrutura disponível, o interesse do cliente e a viabilidade do uso dos motéis para a realização de eventos e hospedagem.

Como ponto de partida, foram levantadas duas hipóteses. Na primeira delas, o motel é uma opção vantajosa de hospedagem e as pessoas realizariam eventos neste ambiente por serem opções econômicas e inusitadas quando se fala em eventos. Na segunda hipótese, devido a problemas estruturais, tais como: infiltrações, higienização incorreta, falta de adaptações estruturais para receber os portadores de necessidades especiais, entre outros, inviabiliza a utilização do motel como opção de hospedagem e eventos.

Assim, a pesquisa partiu de constatações particulares sobre os atuais motéis na cidade de Campo Mourão, visando buscar teorias e leis existentes, assim como a análise in loco desses estabelecimentos, investigando também a história dos motéis no Brasil e no Mundo, tentando explicar qual a influência na atualidade.

Por fim foi utilizado o método observacional que segundo Gil (2008) é o método mais primitivo, porém o que apresenta o maior grau de precisão nas ciências sociais. Sendo utilizado da observação sistemática em três momentos: primeiro como cliente oculto, que permitiu avaliar a qualidade dos serviços que são oferecidos na rede moteleira de Campo Mourão, como por exemplo: refeições, bebidas, higiene e atendimento. Segundo, através das visitas autorizadas e previamente agendadas com o proprietário do estabelecimento, que possibilitou a entrevista e observação dos equipamentos e serviços. Por fim, a aplicação de questionário pela rede social e e-mail, que possibilitou obter a opinião dos usuários dos motéis sem ter a identidade dos mesmos revelada.
In addition to the traditional use, events at motels are a growing segment at the national level: birthdays, weddings, bachelor parties, bridal showers and book launches. Different, and somehow unusual, love motels offer this possibility to their clients.

In this sense, the aim of this research is to analyze the seven love motels in Campo Mourão as an option for hosting and venue for events. Specifically evaluating the offered services, the available facilities, customer interest and the feasibility of using motels for events and lodging.

As a starting point, two hypotheses were considered. In the first one, the motel is an advantageous lodging option and people would carry out events in there because it is less expensive and an unusual option for an event. In the second case, due to structural problems, such as water infiltration, improper sanitation, no accessible facilities for disabled people, among other things, precludes the use of the motel as a lodging option and for events.

Thus, the research came from specific findings on current motels in the city of Campo Mourão, aiming to survey existing theories and laws, as well as the analysis in loco of these establishments also looking into the history of motels in Brazil and in the world, trying to explain their influence today.

Finally, the observational method was used. According to Gil (2008) it is the most primitive method, but the most accurate in social sciences. In this research it is used in systematic observation in three moments: first, mystery shopper, which allowed assessing the quality of services that are offered in the motel of Campo Mourão, such as: meals, drinks, hygiene and service. Second, the scheduled and authorized visits with the owner of the establishment, which enabled the interview and observation of equipment and services. Finally, the electronic-applied questionnaire (social media and e-mail), which enabled obtaining the opinion of the motel's guests without disclosing their identity.

\section{THE LOVE MOTELS IN HISTORY}

It was carried out a review on existing theories to research about hotels as an accommodation option and a venue for events. However, it was difficult to develop this topic because it is still a little discussed 
OS MOTÉIS NA HISTÓRIA

Para refletir sobre os motéis como opção para hospedagem e eventos foi necessário o levantamento das teorias existentes. Porém, a dificuldade para desenvolver esse tópico foi consideravelmente grande, pois no meio acadêmico pouco se fala a respeito dos motéis. Segundo Borella (2009, p. 9), "o setor é de certa forma, negligenciado pela sociedade", o que pode justificar a falta de bibliografias a respeito do objeto de pesquisa.

Porém, alguns esclarecimentos existem na monografia apresentada por Carvalho (2003, p.

16), onde descreve que o surgimento dos motéis se deu após a segunda guerra mundial:

Os motéis, ou motor hotels, termo usado pela primeira vez em 1926 na Califórnia, surgiram nos EUA, no princípio da década de 20 do séc XX, com a expansão do transporte individual em automóvel, e ganhou força na década de 50 em decorrência do desenvolvimento automobilístico e tecnológico no pós Segunda Guerra Mundial (Carvalho, 2003, p. 16).

Outra contribuição sobre o histórico dos motéis está no artigo científico "Considerações sobre Motéis como Atitude Empresarial no Ordenamento Jurídico", onde a autora descreve que os "motéis eram hospedarias de beira de estrada, destinadas aos motoristas e viajantes em trânsito. Distantes dos centros urbanos acabaram sendo utilizados por pessoas em busca de privacidade" (Souza, 2012, p. 53).

Segundo Walker (2002, p. 103), os "hotéis e motéis de auto-estradas ganharam visibilidade durante as décadas de 1950 e 1960", onde após a segunda guerra mundial, nos países desenvolvidos, houve o aumento da renda da população que ocasionou o aumento no número das viagens por parte dos americanos que passaram a necessitar de serviços básicos e baratos. Walker também descreve que,

Os hóspedes podiam entrar dirigindo, parar ao lado da recepção, registrar-se e estacionar seus automóveis do lado de fora dos quartos. Com o passar dos anos, as instalações foram se refinando: apareceram saguões, restaurantes, piscinas, máquinas de bebidas, salão de jogos e televisão via satélite (Walker, 2002, p. 103). subject in academic circles. According to Borella (2009, p. 9), "the sector is somewhat neglected by society", which may explain the lack of literature about the object of research.

However, the monograph presented by Carvalho (2003, p. 16) throw some light on the issue, describing the appearance of motels after World War II:

\begin{abstract}
Motels or motor hotels, a term first used in 1926 in California, appeared in the US at the beginning of the $1920 \mathrm{~s}$ of the $20^{\text {th }}$ century, with the expansion of private transport by car, and gained momentum in the 1950s as a result of automobile and technological development in the post -World War II (Carvalho, 2003, p. 16).
\end{abstract}

Another contribution to the history of motels comes from the article "Considerations about Motels as Business Attitude in Juridical System", wherein the author describes that the "motels were roadside inns, for drivers and travelers in transit. Far away from urban centers they ended up being used by people in search of privacy" (Souza, 2012, p. 53).

According to Walker (2002, p. 103), the "hotels and motorway motels gained visibility during the 1950s and 1960s"; after World War II in developed countries, especially in America, there was an increase in income of the population that intensified the number of trips and the need for basic and cheap services of lodging. Walker also describes that,

$$
\begin{aligned}
& \text { guests could enter driving, stop next } \\
& \text { to the reception, sign up and park their } \\
& \text { cars outside the rooms. Over the years, } \\
& \text { the facilities were improved: lobbies, } \\
& \text { restaurants, pools, drinks machines, } \\
& \text { games room and satellite TV gradually } \\
& \text { made their appearance (Walker, 2002, } \\
& \text { p. 103). }
\end{aligned}
$$

Even without much literature about the rise of motels, the three authors presented above, Carvalho, Souza and Walker, are unanimous in saying that the appearance of hotels or motels roadside in the US (United States) occurred after World War II, when the auto expansion occurred and the population began to travel more, both for leisure and for business purposes. Thus, this kind of lodging has become practical for its location and low cost.

In Brazil, there are not any studies that show how the motels appeared in the country. There are some descriptions from the time of colonization by the Portuguese, but specific literature on the subject is scarce. Given 
Mesmo não tendo muitas bibliografias a respeito do surgimento dos motéis, os três autores apresentados acima, Carvalho, Souza e Walker, são unânimes ao dizerem que o surgimento dos hotéis ou motéis de beira de estrada, nos EUA, se deu após a segunda guerra mundial quando houve a expansão automobilística e a população passou a viajar mais, tanto para o lazer quanto pela necessidade do homem em ganhar novos territórios e buscar o aumento da renda. Assim, esse meio de hospedagem se tornou prático e acessível, principalmente pelo baixo custo e pela localização.

Já no Brasil, não há trabalhos que precisem como surgiram os motéis no país, existem algumas histórias da época da colonização do país pelos portugueses, porém material bibliográfico tratando especificamente dos motéis é muito difícil localizar, por isso se faz tão importante as considerações de Carvalho em sua monografia e também as legislações existentes na esfera federal e municipal.

Segundo Carvalho (2003, p. 19), "sabese apenas que os primeiros motéis brasileiros tinham a mesma finalidade que os motéis americanos e europeus", porém com um tipo de clientela diferente, pois no Brasil era "utilizado por casais homo e heterossexuais para encontros reservados" e devido a isso os motéis brasileiros tinham uma estrutura física diferente de outros países. Eram apartamentos luxuosos, confortáveis e com muito erotismo, para que as pessoas pudessem sair da rotina com algo diferente do que tinham em casa.

Ainda segundo Carvalho (2003, p. 22), todo esse processo de transformação nos motéis brasileiros "tem a ver com o comportamento, o estilo, o jeito de ser do brasileiro, a miscigenação cultural", tantos povos que vieram para o Brasil desde a época da colonização e se depararam com o povo indígena, sem pudor e sexualmente falando, eram totalmente liberais, tanto que as moças indígenas podiam manter relações sexuais com quem quisessem, sem serem desonradas.

Conta a história que os portugueses vieram para o Brasil fugidos e aqui quiseram impor as morais e os bons costumes europeus. Deparando-se com tanta liberdade sexual dos indígenas, eles abusavam das mulheres e assim nasceram as primeiras gerações de mestiços. O povo brasileiro, como descreve Carvalho (2003, p. 24), "herdou uma cultura tão rica e miscigenada, que se tornou único, singular".

Provavelmente todo esse tabu ainda encontrado se deva a essa época de exploração this, Carvalho's monography and the existing legislation, at the federal and municipal level, is of great importance.

According to Carvalho (2003, p. 19), "it is known only that the first Brazilian motels had the same purpose as the American and European motels ", but with a different type of customers, because in Brazil they were "used by homo and heterosexual couples for private meetings" and because of this, Brazilian motels' facilities were different from other countries. They offered luxury, comfort and eroticism, so that people could escape from routine.

Also according to Carvalho (2003, p. $22)$, this whole process of transformation in Brazilian motels "has to do with Brazilian way of living, behavior and manner, the cultural miscegenation". The different people who came to Brazil since the colonization have encountered indigenous peoples, sexually liberated. In their societies, women could have sex with anyone they wanted without being dishonored.

The history tells us that the Portuguese came to Brazil as fugitives, and here they wanted to impose European morals and customs. Faced with the indigenous' sexual freedom, they abused women and so the first generation of mestizos were born. The Brazilian people, as described by Carvalho (2003, p. 24), "inherited a culture so rich and mixed-race, that has become unique, singular."

Probably, the taboo still existing stems from those days of exploitation that the indigenous, then black and finally white women have endured.

Gradually, under the influence of the church, conservative families have started to arise and influenced changes in the mindset, "where at home respect is observed and out of it everything is permitted" (Carvalho, 2003, p. 25).

Given the women exploitation, and under the influence of the church, families began to praise women's virginity and raising girls to be wives, mothers and caregivers of husbands. Divorce was unacceptable, so the extramarital affairs have become frequent and as motels offered suitable rooms for these meetings and were discrete, they have become popular among couples seeking for privacy and fulfillment of sexual fantasies.

Given this, it is observed that at first the motels were used to accommodate travelers, especially in the US and Europe, and only in Brazil, they have assumed a different 
que viveram as índias, depois as negras e por fim as mulheres brancas.

As famílias conservadoras, por influência da igreja, começaram a aparecer aos poucos e mesmo com todo esse cenário sempre tiveram papel muito importante, mas "com seus preconceitos onde dentro de casa se guarda o respeito e fora dela tudo pode" (Carvalho, 2003, p. 25).

Mediante a tanta exploração, e também à influência da igreja, as famílias passaram a educar as mulheres para constituir família, tendo que casar virgem, criar os filhos e cuidar do marido. Era inaceitável o divórcio, assim as relações extraconjugais tornaramse frequentes e como os motéis ofereciam apartamentos apropriados para esses encontros e ainda mantinham a descrição e o sigilo, esses passaram a ser procurados para a realização de fantasias sexuais e se tornaram o meio de hospedagem preferido para o encontro de casais.

Com toda essa história, observa-se que de início os motéis eram utilizados para hospedagem de viajantes, principalmente nos EUA e na Europa, e só no Brasil, é que assumiu uma característica diferenciada. Até em filmes podemos perceber essa diferenciação. Os filmes estrangeiros trazem os motéis sendo utilizados como hotéis de beira de estrada e, nos filmes brasileiros, os motéis, quando aparecem, mostram encontros, principalmente extraconjugais.

ESCLARECIMENTOS CONCEITUAIS

Em se falando de Brasil, a princípio toda e qualquer regulamentação sobre os estabelecimentos hoteleiros era feita pelo Ministério da Economia, até porque existiam poucas pastas. Assim, esse ministério, publicou em 04 de julho de 1997 o DecretoLei no $167 / 97$, onde no artigo $2^{\circ}$ conceitua que os estabelecimentos hoteleiros são "(...) os empreendimentos turísticos destinados a proporcionar, mediante remuneração, serviços de alojamento e outros serviços acessórios ou de apoio, com ou sem fornecimento de refeições" (Brasil M. , 1997, p. 2).

Já, em 25 de setembro de 1997, o Ministério da Economia publicou o Decreto Regulamentar no 36/97, onde em seu artigo $2^{\circ}$ (Brasil M. , 1997, p. 1), traz que os estabelecimentos hoteleiros são divididos em grupos sendo: "a) Hotéis; b) Hotéis-apartamentos (aparthotéis); characteristic. Even in movies this difference can be observed. Foreign films depict motels as roadside hotels and in Brazilian films, motels, when they appear, are related to rendezvous, particularly extramarital affairs.

\section{CONCEPTUAL CLARIFICATION}

Regarding Brazil, initially the Accommodation Regulations fall within the competence of the Ministry of Economy. So this ministry, published on July 4, 1997 the Decree-Law No. 167/97, which in Article 2 defines hotel establishments "(...) the tourist developments aimed at providing, for a fee, accommodation and other support services, with or without catering services" (Brazil M. , 1997, p. 2).

Already, on September 25, 1997 the Ministry of Economy published the Decree No. 36/97, which in Article 2 (Brazil M. , 1997, p. 1), sates that the hotel establishments are divided into groups: "a) Hotels; b) Apartments hotels (aparthotel); c) Pensions; d) Guesthouses; e) Motels; f) Inns". Conceptualizing the motels, Article 41 states:

\begin{abstract}
Motels are lodging establishments located outside urban centers and near the roads made up of independent housing units with direct entrance from outside and with a private parking space, adjacent to the accommodation unit (Brazil M., 1997, p. 6).
\end{abstract}

Despite the Ministry of Economy classification of motels as lodging facilities, the Ministry of Tourism, which become an independent Ministry in 2003, only classified lodging facilities, in the Article 7 of Ordinance No. 100 of June 16, 2011 (Brazil M., 2011, pp. 2-3) as: hotel, resort, farm hotel, bed and breakfast, historic hotel, hostel and aparthotel, describing each of them and not referring motels as lodging facilities.

A classification can be found in a booklet entitled: "Technical specification - Motel" released by the Brazilian Support Service for Micro and Small Enterprises (SEBRAE) which states that the motels were used by people looking for privacy to have sex and not only to rest.

Motel is a kind of hotel, but with the difference that people attend it to spend intimate moments next to someone they love in a modern, warmth atmosphere, and not necessarily to achieve accommodation (SEBRAE, [n.d]). 
c) Pensões; d) Estalagens; e) Motéis; f) Pousadas". Conceituando os motéis no artigo $41^{\circ}$ como:

Motéis são os estabelecimentos hoteleiros situados fora dos centros urbanos e na proximidade das estradas constituídos por unidades de alojamento independentes, com entradas directas do exterior e com um lugar de estacionamento privativo e contíguo à unidade de alojamento (Brasil M. , 1997, p. 6).

Mesmo com o Ministério da Economia classificando os motéis como estabelecimentos hoteleiros, o Ministério do Turismo, após tornar uma pasta autônoma no ano de 2003, só estabeleceu os meios de hospedagem, no artigo 70 da portaria $\mathrm{n}^{\circ} 100$ de 16 de junho de 2011 (Brasil M. , 2011, pp. 2-3) como sendo: hotel, resort, hotel fazenda, cama e café, hotel histórico, pousada e flat/apart-hotel, caracterizando cada um deles e não citando os motéis como meios de hospedagens.

Uma conceituação pode ser encontrada no livreto denominado: "Ficha Técnica - Motel" lançado pelo Serviço Brasileiro de Apoio às Micro e Pequenas Empresas (SEBRAE) que afirma que os motéis eram utilizados por pessoas em busca de privacidade e com o objetivo de manter relações sexuais e não somente pouso.

\begin{abstract}
Motel é uma espécie de hotel, mas com a diferença de que as pessoas o frequentam com o objetivo de passar momentos de intimidade ao lado de quem se ama, num ambiente moderno e aconchegante, e não necessariamente para conseguir alojamento (SEBRAE, n.d.).
\end{abstract}

$\mathrm{Na}$ academia simples, mas importante definição é apresentada por Beni (2004, p. 331). Para ele o motel é um "meio de hospedagem que aluga apartamentos mobiliados, possuindo também serviços completos de alimentação, situado à margem de rodovias".

Outro conceito que podemos também abordar nesse tópico é o da autora Giaretta (2005, p. 797) que enquadra os meios de hospedagem que não se encontravam credenciados ou classificados pelos órgãos oficiais, como "hospedagem alternativa", considerando esses, como:

(...) meio de hospedagem não convencional aquele que complementa a oferta de leitos nos destinos
In academia, a simple but important definition is put forward by Beni (2004, p. 331). For him, the motel is a "means of hosting which rents furnished apartments, also having complete supply of services, located near highways."

Another concept that can also be addressed is the one by Giaretta (2005, p. 797) an author that envisages the lodging facilities that are not accredited or classified by official agencies, as "alternative accommodation", considering this as

unconventional hosting means one
that complements the supply of bed-
spaces in tourist destinations and is
characterized by being more economical
than conventional hosting, with great
variation in the services offered
(Giaretta, 2005, p. 798).

Although Giaretta does not mention motels as alternative accommodation, the motel chain when used for lodging, especially in the case of major events, can be considered as such. Thus, the Ministry of Tourism given that it is the only official department which regulates tourism should address the motels as a means of lodging.

Therefore, it can be observed that, in Brazil, the motels were first classified as hotel establishments and then they were ignored as a lodging facility. Perhaps due to their association to sex or eroticism.

It is noteworthy that, according to the various concepts, the motels are constantly changing, from lodging to travelers, places to secret meetings and now returning gradually to its origins as a lodging facility. Some still maintain the luxurious character and erotic feature, but most have already a more executive character, affordable and becoming increasingly an accommodation option.

This setback in the history of motels may be due to the development of cities and of changes in customs and consumption; in many cities motels have become a part of their own neighborhoods and similar to other hotels (Souza, 2012, p. 53).

Another change is the realization of events in these spaces, even if "speaking in motels is often talking about something sinful, almost forbidden, and causing surprise or distrust of others" (Carvalho, 2003, p. 21). Events in motels have become frequent, mainly in large cities.

The National Service for Commercial Training (SENAC) defines "event as something that results from well-designed and executed 
turísticos e tem como característica ser mais econômico que a hospedagem convencional, apresentando grande variação quanto à prestação de serviços (Giaretta, 2005, p. 798).

Embora Giaretta não mencione os motéis como meio de hospedagem alternativa, a rede moteleira quando utilizada para hospedagem, principalmente em época de grandes eventos, possa ser considerada como tal. Assim, o Ministério do Turismo, a única fonte citada que não caracteriza e nem conceitua os motéis, deveria ser o principal a tratar os motéis como meio de hospedagem até mesmo porque esta pasta é quem dita as regras para o desenvolvimento do turismo.

Percebe-se então que, no Brasil, num primeiro momento, os motéis foram classificados como estabelecimentos hoteleiros e depois não foram nem citados como meios de hospedagem. Talvez isso se deva à característica erótica que os motéis tenham assumido desde o princípio.

Vale ressaltar que, mediante a tantas conceituações, nota-se que os motéis estão em constante mudança, passando de hospedagem para viajantes, a locais para encontros secretos e hoje voltando, aos poucos, à origem de meios de hospedagem. Alguns ainda mantêm a característica luxuosa e o erotismo, porém a maioria já possui uma característica mais executiva, com preços acessíveis e tornando-se cada vez mais um meio de hospedagem.

Esse retrocesso na história dos motéis pode ser devido ao desenvolvimento das cidades e à mudança de costumes e consumos da sociedade, onde os motéis, em muitas cidades, passaram a fazer parte dos próprios bairros, e assemelharam-se muito aos hotéis (Souza, 2012, p. 53).

Outra mudança é quando da realização de eventos nesses espaços, embora "falar em motéis, muitas vezes, é falar de algo pecaminoso, quase proibido, e provocar a surpresa de uns ou a desconfiança de outros" (Carvalho, 2003, p. 21). Os eventos em motéis têm se tornado constantes principalmente nos grandes centros.

O Serviço Nacional de Aprendizagem Comercial (SENAC) denomina que "evento é um acontecimento que resulta de projetos bem elaborados e executados, onde trabalhamos com objetivos e públicos previamente definidos" (SENAC, 2011, p. 9), classificando os eventos como sociais e empresariais. projects, bearing in mind pre-defined objectives and publics" (SENAC, 2011, p. 9), classifying events as social and business.

A social event, according to Meirelles (1999, p. 29), "aims only at the social interaction". As for the business events they are most often used for the launch of a product or even a new brand:

(...) Is an institutional and promotional tool, used in targeted communication, in order to create concept and establish the image of organizations, products, services, ideas and people, through a pre-planned event, taking place in a single time frame in which participants are close to each other either physically or through technology (Meirelles, 1999, p. 21).

However, for this type of activity to occur in a motel, it is necessary to analyze its basic facilities. According to SEBRAE ([n. d.], p. 2), a motel basic structure "should have a minimum area of $550 \mathrm{~m}^{2}$, which will be distributed between office, laundry room, kitchen, office, reception and suites."

Another point that should be considered are the indoor facilities and equipment that should be included in the basic design:

(...) Laundry washers, dryers and industrial ironers (for laundry). Freezers, refrigerators, stoves, refrigerated counters, food processors, etc. (for the kitchen). Tables, chairs, file cabinets, computers, telephone, fax, etc. (for office and reception). Double beds, mini-fridges, color TV, stereos, air conditioners, etc. (for suites) (SEBRAE, [n. d.], p. 2).

It must also be noted that motels have to address accessibility issues which, for the Brazilian Association of Technical Standards - ABNT is the "possibility to achieve, awareness and understanding to use safely and autonomously buildings, space, furniture, urban equipment and elements" (ABNT, 2004, p. 2). Motels should be prepared to receive users with limited mobility, mild or not.

Thus, the regulatory framework requirements for the hotel sector must be observed in a motel building project; it has to contain rooms prepared to receive this public, who is so often forgotten.

\section{THE MOTELS IN CAMPO MOURÃO}

With regard to the emergence of the motels in the city of Campo Mourão, there is 
Um evento social, segundo Meirelles (1999, p. 29), "visa somente à confraternização entre as pessoas". Já os eventos empresariais são na maioria das vezes, utilizados para o lançamento de um produto ou até mesmo de uma marca nova:

(...) é um instrumento institucional e promocional, utilizado na comunicação dirigida, com a finalidade de criar conceito e estabelecer a imagem de organizações, produtos, serviços, ideias e pessoas, por meio de um acontecimento previamente planejado, a ocorrer em um único espaço de tempo com a aproximação entre os participantes, quer seja física, quer seja por meio de recursos da tecnologia (Meirelles, 1999, p. 21).

Porém, para que esse tipo de atividade ocorra na rede moteleira, faz-se necessário a análise da estrutura básica de cada motel. Segundo o SEBRAE (n.d., p. 2), uma estrutura básica moteleira "deve contar com uma área mínima de $550 \mathrm{~m}^{2}$, que será distribuída entre o escritório, lavanderia, cozinha, escritório, recepção e suítes".

Outro ponto que deve ser levado em consideração são as instalações internas e os equipamentos, que deverão constar no projeto básico:

(...) lavadoras, secadoras e passadeirasindustriais (para a lavanderia). Freezer, geladeiras, fogões, balcões-refrigerados, processadores de alimentos, etc. (para a cozinha). Mesas, cadeiras, arquivos de aço, computadores, telefone, fax, etc. (para o escritório e recepção). Camas de casal, frigobares, TV's coloridas, aparelhos de som - ambiente, aparelhos de ar condicionado, etc. (para as suítes) (SEBRAE, n.d., p. 2).

Há de se destacar também, que a rede moteleira precisa se preocupar com a acessibilidade, que para a Associação Brasileira de Normas Técnicas - ABNT é a "possibilidade e condição de alcance, percepção e entendimento para a utilização com segurança e autonomia de edificações, espaço, mobiliário, equipamento urbano e elementos" (ABNT, 2004, p. 2). Os motéis devem estar preparados para receberem usuários com dificuldade de locomoção, seja essa leve ou não.

Assim, no projeto de construção de um motel deve se observar as normas gerais da hotelaria, devendo conter apartamentos para receber esse público que tantas vezes é discriminado. no literature or information about it. The city has a general regulatory framework regarding the hospitality industry, including motels, but there is no specific regulations for the motel activity.

According to information obtained from the Municipality of Campo Mourão (2013, p. $1)$, there are seven motels operating in the city, which will be identified in this work by the letter " $M$ " following by a number: $M 1, M 2$, M3, M4, M5, M6 and M7. All these have been surveyed.

It was observed during the research that the city motels present more luxury and erotic features, being used especially for sexual encounters and hardly for overnight staying. Of the seven motels, three are in the urban area and the other four, out of town.

The motel M1 has twelve suites. The M2 provides three master bedroom suites, three Presidential Suites, eighteen rooms, totaling 24 housing units (HU). Already in M3 motel totaling up nineteen $\mathrm{HU}$ being: a presidential suite, six master suites and thirteen rooms. The M4 has fourteen rooms, the M5 has ten rooms and M6 has eleven. Finally, the motel identified as M7 offers five suites and fourteen rooms.

It is noteworthy that during the search the motel here identified as M6 has closed business, so it is not mentioned in the results.

\section{DATA ANALYSIS}

Mystery shopper observation took place from November 2013 to August 2014, the following items were evaluated:

1. Service quality - reception and room service;

2. Accessibility - garage, bathroom, handrail and ramp;

3. Cleanliness - bedroom, bathroom, hot tub, bedding and bath;

4. Conditions of the equipment - TV set, radio, air conditioning, refrigerator, sofa and bed;

5. Food - fresh or frozen and variety of food provided;

6. Beverages - variety and serving temperature.

After setting these items, a classification was assigned: poor, fair, good or excellent. Only item 2 has been assigned a "Yes" or "No" 
OS MOTÉIS EM CAMPO MOURÃO

No que diz respeito ao surgimento dos motéis na cidade de Campo Mourão, não existem bibliografias e informações a respeito. Há leis no município sobre algumas regulamentações no setor hoteleiro, incluindo os motéis, porém nenhuma lei municipal específica para a atividade moteleira.

Conforme informação obtida na Prefeitura Municipal de Campo Mourão (2013, p. 1), na cidade existem sete motéis ativos sendo esses identificados, nesse trabalho, pela letra " $\mathrm{M}$ " e por números, assim temos: M1, M2, M3, M4, M5, M6 e M7. Todos esses investigados.

Observou-se durante a pesquisa que, em sua maioria, os motéis da cidade apresentam características mais luxuosas e eróticas, sendo utilizados para encontros e dificilmente para a hospedagem de pessoas. Ainda, dos sete motéis, três deles encontram-se no perímetro urbano e os outros quatro, fora da cidade.

O motel M1 apresenta doze suítes. O M2 disponibiliza três suítes máster, três suítes presidenciais, dezoito apartamentos, totalizando 24 unidades habitacionais (UH). Já no motel M3 totalizam-se dezenove UH sendo: uma suíte presidencial, seis suítes máster e treze apartamentos. O M4 conta com quatorze apartamentos, o M5 com dez e o M6 com onze apartamentos. Por fim, o motel identificado como M7 disponibiliza cinco suítes e quatorze apartamentos.

Vale ressaltar que no decorrer da pesquisa o motel aqui denominado como M6 teve as suas atividades encerradas, assim esse não será citado durante a apresentação dos resultados.

\section{ANÁLISE DOS DADOS}

As observações, como cliente oculto, foram realizadas no período de novembro de 2013 a agosto de 2014, sendo observados os seguintes itens:

1. Qualidade do atendimento - recepção e serviço de quarto;

2. Acessibilidade - garagem, banheiro, barra de apoio e rampa de acesso;

3. Limpeza - quarto, banheiro, banheira de hidromassagem, roupas de cama e banho;

4. Condições dos equipamentos aparelho de TV, rádio, ar condicionado, frigobar, sofá e cama; answer, because this verifies the existence of conditions for receiving a person with limited mobility. The results are shown in Table 1 Results of mystery shopper observation, in Appendix.

Item "1) Service quality", the motel M1 was classified as "Poor" because there was nobody in the reception, the gate was open and the wait was long; M2, M4 and M5 were rated "Good" due to delays in room service; and M3 and M7 received "Excellent", both the reception service and the room service were prompt and courteous.

In terms of accessibility for guests with special mobility needs, item 2, only the M3 and M5 motels are able to receive, for example, a wheelchair. Motels M1, M2, M4 and M7 do not meet the ABNT standards and also lack space for adaptations.

With regard to the cleanliness of rooms and suites examined (item 3 ), only the motel M1 showed improper cleaning; the M2 and M5 were rated "Good" because bed and bath linen presented, sometimes, smell of smoke and lack of softness; in turn, M3, M4 and M7 obtained "Excellent" rate.

With respect to the equipment available in the HU's (item 4), the M1 presents old and unmaintained equipment, such as a very noisy and dripping air conditioning unit, a TV which did not work, and it lacked a mini fridge in the room. The M2, M3 and M7 were rated "Good" because the sound equipment are just tuned to local radio stations; already the M4 and M5 have well-maintained equipment in addition to having some different soundtrack options, they are classified as "Excellent".

In item 5, food, M1 was rated "Poor" since it offered no options, either of industrialized food or prepared meals; M5 only offered candy (chocolates and Halls cough drops) being rated as "Fair"; M2, M3, M4 and M7 were rated "Good", they provide industrialized food and a menu with various options, however, they were frozen food portions prepared at customer's request. Classification "Excellent" was not assigned to any of the examined establishments since none of them offered fresh food.

Regarding beverages, M1 offered bottled drinks if requested via room service, hindering the client's consumption, so it was classified "Fair". M2, M4 and M5 were rated "Good" because of the small range of drinks available. However, M3 and M7 obtained "Excellent" 
5. Alimentos - frescos ou congelados e a variedade dos alimentos fornecidos; 6) Bebidas - variedades e temperatura.

Definidos esses itens, foi atribuído a cada um a classificação: ruim, regular, bom e ótimo. Apenas no item 2 que foi atribuído: "Sim" ou "Não" pois esse se refere a UH apresentar ou não condições estruturais para receber uma pessoa com dificuldade de locomoção. Assim, chegamos aos resultados apresentados pela autora, na Tabela 1 - Resultado observação cliente oculto que segue no anexo.

No item "1) atendimento", o motel M1 obteve classificação "Ruim", devido à portaria estar sem atendente, ao portão aberto e à demora no atendimento; os M2, M4 e M5 foram classificados como "Bom", devido à demora no atendimento do serviço de quarto; e o M3 e o M7 receberam "Ótimo", pois tanto o atendimento da recepção quanto o serviço de quarto apresentaram atendimentos imediatos e cordiais.

Em se tratando de estrutura para o recebimento de clientes com necessidades especiais de locomoção, item 2, apenas os motéis M3 e M5 têm condições de receber, por exemplo, um cadeirante. Os motéis $M 1, M 2$, M4 e M7, além de não se enquadrarem nas normas da ABNT para acessibilidade, também não possuem espaço físico para adaptações.

No que diz respeito à limpeza dos apartamentos e suítes estudados (item 3), apenas 0 motel M1 apresentou limpeza inadequada; o M2 e M5 receberam classificação "Bom", devido às roupas de camas e banho apresentarem, algumas vezes, cheiro de fumaça e falta de maciez; já o M3, M4 e M7 obtiveram classificação "Ótimo".

Dos equipamentos disponíveis nas UH's (item 4), o M1 é o que apresenta os equipamentos mais antigos e sem manutenção, como por exemplo, o ar condicionado ser muito barulhento e pingar muita água no recinto, o aparelho de TV não funcionar, além de não possuir frigobar no apartamento. $O$ M2, M3 e o M7 receberam classificação "Bom", pois os equipamentos de som estão apenas sintonizados em rádios locais; já o M4 e o M5 possuem equipamentos em ótimo estado de conservação além de possuírem algumas opções de trilha sonora diferenciada, sendo classificados como "Ótimo".

No item 5, alimentos, o M1 não apresentou opção, seja ela de alimentos industrializados ou pratos prontos, por isso rate for their beverage options, ranging from wine and sparkling wine to beer, water and yoghurt, pleasing all types of customers and made available in the fridge within the HU.

From the results presented, the motel M1 showed the lowest grade and M3 presented the best classification, especially in the items: service, accessibility, cleanliness and beverages.

Another moment of the research consisted of open-ended interviews made during authorized visits in the motel establishments of Campo Mourão. The interview aimed to identify the situation of these establishments, if the owners have an interest in providing spaces for events and how often the rooms and suites are used as lodging facilities.

The staff of motels M1 and M2 said they were not authorized to allow the visit and have also refused to respond the questions by phone. Several attempts were made to contact the owner but without success.

In motel M3, the employee was courteous and willing to help, managing to get the owner's authorization for the visit. Thus, at the scheduled day and time the visit, observation and interview were made. Some key points are listed above:

- Existence of rooms that meet ABNT accessibility regulations;

- Cleaning and disinfection of the HU's are done with specific products after they are used and a general housekeeping (walls and garages) is done daily, during the day in the suites, and overnight in the rooms ;

- The rotation of bed and bath linens is made, aimed at their durability;

- The maintenance of equipment is performed by a third-party service provider every week, because, as reported by the employee, there is a large number of people who damage the equipment when using the $\mathrm{HU}$;

- General reforms are made when necessary;

- The establishment has a laundry room and kitchen, but the food, following determinations from the health surveillance service is frozen and only prepared at customer's request;

- Employees do not have a hospitality or tourism degree or specialization, 
recebeu classificação "Ruim"; o M5 possui apenas alimentos industrializados (chocolates e hall's) recebendo classificação "Regular"; já o M2, M3, M4 e M7 disponibilizam alimentos industrializados e um cardápio com opções variadas, porém, são porções de alimentos congelados e preparados conforme o pedido do cliente, assim receberam classificação "Bom". A classificação "Ótima" não foi atribuída a nenhum dos estabelecimentos investigados, afinal nenhum deles disponibiliza comidas frescas e preparadas na hora.

$\mathrm{Em}$ relação às bebidas comercializadas, - M1 oferece bebidas em garrafas desde que solicitadas através do serviço de quarto, dificultando o consumo do cliente, por isso classificação "Regular". O M2, M4 e M5 receberam classificação "Bom", devido à pequena variedade de bebidas disponíveis. Já o M3 e o M7 obtiveram classificação "Ótima", pois disponibilizam desde vinho e espumante, até cerveja, água e iogurte, agradando a todos os tipos de clientes e sendo esses disponíveis no frigobar dentro da própria UH.

Mediante os resultados apresentados, o motel M1 foi o que apresentou classificação inferior a todos os outros, e o M3 o que apresentou melhor classificação, principalmente nos itens: atendimento, acessibilidade, limpeza e bebidas.

Outro momento da pesquisa contou com a realização de entrevista, com perguntas abertas, durante as visitas autorizadas nos estabelecimentos moteleiros de Campo Mourão. A entrevista teve o intuito de identificar a situação desses estabelecimentos, se os proprietários têm interesse em disponibilizar espaços para a realização de eventos e com qual frequência os apartamentos e suítes são utilizados como meios de hospedagem.

Assim, quando do contato com os motéis M1 e M2 as funcionárias não tinham autorização para liberar a visita e também não quiseram responder às perguntas por telefone. Foram efetuadas várias tentativas de contato com o proprietário, porém sem sucesso.

No motel M3, além da funcionária ser cordial e mostrar interesse em ajudar, ainda conseguiu autorização do proprietário para que a visita fosse realizada. Assim, no dia e hora marcada, a visita foi efetivada, observações e questionamentos foram feitos, sendo então elencados alguns pontos principais:

- Existência de apartamentos que se enquadram nas normas da ABNT para acessibilidade; having acquired on job knowledge and experience; they work on schedules.

Regarding holding events in the facilities of the motel M3, the answer was positive, however it was pointed out that it would not be feasible either for the client or for the establishment. To the customer due to the cost, because it is calculated the value for the couple, and for the establishment it is more profitable the two-hour rental; also, an event implies a bigger movement of people which may compromise the privacy and confidentiality of other customers. Not to mention that the M3 has only one suite which could be used to host an event with a maximum of ten people, and also it does not have structural conditions to adapt other suites for events.

With regard to hosting in times of major events in the city, the answer was negative, because according to the employee, renting by the hour is more profitable to the motel than daily rate, but also reported that, due to the location of M3, it is common the overnight staying of at least four guests during the week days.

Motels M4 and M5 did not respond to the phone contact and when a face-to-face contact was attempted there was no attendant interested in contributing to the survey, the owner was not present.

At the motel M7, although the difficulties in contacting the owner, due to his absence at various times; when finally the contact succeeded he was very friendly and immediately authorized a visit. Some issues were identified:

- There are no rooms or suites for people with special needs, but there is already a project that will be running soon for the necessary adjustments;

- The cleaning and disinfection of HU's are made with specific products after each use;

- It is made the rotation of bedding and bath linens to ensure their durability;

- There is a specific employee in charge of preventive maintenance of equipment;

- General reforms are made when necessary;

- The establishment has in-house laundry and a staff member is in charge of the whole process of washing, drying, ironing and storage all the linens; 
- A limpeza e desinfecção das UH's são feitas com produtos próprios após cada utilização, além de ser feita a limpeza geral (paredes e garagens) diariamente, sendo no período do dia efetuada a limpeza geral nas suítes e no período noturno, nos apartamentos;

- É feito o rodízio das roupas de cama e banho, visando a maior durabilidade do enxoval;

- A manutenção dos equipamentos é efetuada por uma empresa terceirizada, semanalmente, pois conforme relato da funcionária é elevada a quantidade de pessoas que danificam os equipamentos quando da utilização da UH;

- As reformas gerais são feitas quando necessário;

- O estabelecimento possui lavanderia e cozinha própria, porém os alimentos, conforme determinações da vigilância sanitária, são todos congelados e preparados apenas quando solicitado pelo cliente;

- Os funcionários não possuem cursos de graduação ou especialização na área de hotelaria, tendo adquirido conhecimento e experiência com a prática do dia-a-dia e trabalham por escalas de horário.

Quando do questionamento sobre a realização de eventos nas dependências do motel M3, recebeu-se uma resposta positiva, porém com a ressalva de que não é viável nem para o cliente nem para o estabelecimento. Para o cliente devido ao custo, pois é calculado o valor referente ao casal e para o estabelecimento, por ser mais rentável o aluguel fracionado a cada duas horas, além de que, com a realização de um evento a movimentação de pessoas é maior, podendo colocar em risco a privacidade e o sigilo da identidade de outros clientes. Sem contar que o M3 apresenta apenas uma suíte que comporta a realização de um evento, sendo este com capacidade para aproximadamente dez pessoas e também não apresenta condições estruturais para adequação de outras suítes para eventos.

No que diz respeito à hospedagem em época de grandes eventos na cidade, a resposta foi negativa, pois segundo a funcionária é mais rentável para o motel o fracionamento
- It has a kitchen, but mostly serves frozen and industrialized foods. Fresh food only for breakfast and portions of chicken and fries.

- Employees are registered, work on schedules, and have acquired on-job knowledge.

Regarding the use of the rooms for alternative accommodation, the owner reports that the demand for bedrooms and suites for overnight, occurs only on weekends, mostly couples from neighboring looking for a new experience, a total of four to five-overnight staying per weekend. It seldom receives guests for overnight staying from Monday to Friday; the owner believes that it is not viable for the establishment to offer this type of service, even when there are major events happening in the city.

With regard to the use of suites for holding events, the owner is favorable; although currently there is no space for more than six people, the motel is undergoing renovations and such a space is being prepared. When asked about the profitability of this type of service, he says it is profitable due to the sales of drinks, and he reports that the motel has been receiving calls from customers looking for a distinctive space for holding an event.

About overnights staying, the difference between M3 and M7 is the location, the former is near the highway in one of the Campo Mourão entrances, making the access easier.

The authorized visit brought relevant information about the procedures adopted by the owners to improve the accessibility and the interest in holding events in their establishments.

As a mystery shopper, one can see the factual reality of motels as a means of hosting and experience the issues raised by the entrepreneurs' management decisions.

In the final stage of this research, a questionnaire was administered via email and social network "Facebook"; between August 28 and September 15, 2014 it got forty replies. The questionnaire presented eight questions, addressing the socioeconomic profile and demand for motel services.

Of the forty responses received, 67 percent were answered by people aged 18-30 years old, 28 percent by 31 - to 45 -year-old people and 5 percent by 46 - to 60 -year-old respondents. In relation to gender, 57 percent were female and 43 percent were male. 
de horas e não o pernoite, porém informou que devido à localização do M3, de segunda a sexta feira, é comum o pernoite de pelo menos quatro viajantes por dia.

Os motéis M4 e M5 não responderam ao contato por telefone e quando da tentativa do contato pessoal não houve interesse do atendente em contribuir com a pesquisa, o proprietário não se fazia presente.

No motel M7, apesar da dificuldade para conseguir falar com o proprietário, devido sua ausência em diversos momentos, quando conseguimos, o mesmo foi muito solícito e autorizou a visita no mesmo instante, assim foram identificadas algumas situações:

- Não possui apartamentos ou suítes para portadores de necessidades especiais, porém já possui um projeto para as adaptações necessárias, que será executado em breve;

- A limpeza e desinfecção das UH's são feitas com produtos próprios após cada utilização;

- É feito o rodízio das roupas de cama e banho visando a maior durabilidade do enxoval;

- Possui um funcionário específico para a manutenção preventiva dos equipamentos;

- As reformas gerais são feitas quando necessário;

- O estabelecimento possui lavanderia própria e um funcionário responsável por todo o processo de lavar, secar, passar e armazenar todo o enxoval;

- Possui cozinha equipada, porém, em sua maioria, é servido alimento congelado e industrializado. Alimentos frescos apenas no café da manhã e as porções de frango e batata frita.

- Os funcionários são registrados, trabalham por escalas, e o conhecimento adquirido na prática das funções exercidas no motel.

Quanto à utilização dos apartamentos para a hospedagem alternativa, o proprietário informa que a procura de apartamentos e suítes para pernoite, ocorre apenas nos finais de semana, sendo esses, em sua maioria, casais de municípios vizinhos à procura de uma experiência nova, totalizando quatro há cinco pernoites por final de semana. De segunda a sexta feira, raramente recebe
Related to the amount of times that the motel chain is used in the city of Campo Mourão every year, 23 percent of respondents have never used the motel chain of the city, 12 percent use it at least once a year, 10 percent twice a year, 7 percent thrice a year, and 48 percent say they use these services more than four times a year. It is noteworthy that the questionnaire was sent to several people in the city of Campo Mourão, and some neighboring towns, which can justify the 23 percent of people who have never used the services of the motel chain in the researched city.

On the item type of accommodation, we can see that most of the people, (66 percent) opt for a standard room, and 34 percent use a suite, it is believed that the cost is taken into consideration when choosing the type of bedroom accommodation.

With regard to the accessibility of the facilities, such as: bathroom, handrail, parking and ramp access to attend people with special needs, 80 percent of people claim that there are not accessibility standards and 20 percent say otherwise.

Another disputed point is, both in motels and in hotels, the cleanliness of the premises; the questionnaires showed that only 3 percent of respondents consider the cleaning excellent, the majority (65 percent) rate the cleanliness as good, as 25 percent consider it fair and 7 percent poor. It is noteworthy that the customer pays attention to this issue and is increasingly demanding.

The seventh question deals with the use of motels for holding events, and 52 percent of people said they would participate in an event organized in a motel, 25 percent said maybe, and 23 percent would not attend to it.

The last question sought to identify if people would stay in a motel if the hotel chain of the city had been overcrowded; 77 percent of people would stay without any problem, 15 percent maybe and only 8 percent said no.

\section{FINAL CONSIDERATIONS}

It was verified that the motels in the city of Campo Mourão have easy access mainly because they are by the side of the roads, which facilitates the entry and exit of people. With regard to confidentiality, basic feature of a motel, this is being somehow impaired due to the city's growth with several companies being installed near to motels. 
viajantes para pernoite, acreditando não ser viável para o estabelecimento oferecer esse tipo de serviço também em época de grandes eventos na cidade.

No que diz respeito à utilização de suítes para a realização de eventos, o proprietário é favorável, embora hoje não possua um espaço que comporte mais que seis pessoas, porém o motel está passando por reformas e esse espaço está sendo preparado. Quando questionado sobre a rentabilidade desse tipo de serviço, afirma que é rentável, pois o lucro é obtido na bebida que será comercializada, informando ainda que várias são as ligações recebidas de clientes à procura de um espaço diferenciado para a realização de evento.

Na questão pernoite, a diferença entre M3 e M7 é a localização, aquele fica à margem da rodovia de uma das entradas de Campo Mourão, facilitando o acesso.

A visita autorizada trouxe relevantes informações acerca dos procedimentos adotados pelos proprietários para melhorar a acessibilidade e sobre o interesse em realizar eventos em seus estabelecimentos.

Colocando-se como cliente oculto, podese observar a realidade fática dos motéis como meio de hospedagem, vivenciando os problemas surgidos pelas políticas empresárias empregadas no sistema.

Como última fase desta pesquisa, foi efetuado questionário através de e-mail e rede social facebook, onde no período de 28 de agosto a 15 de setembro de 2014 foram registradas quarenta respostas. Neste foram apresentadas oito questões, abordando perfil socioeconômico e as demandas pelos serviços moteleiros.

Das quarenta respostas recebidas, 67\% foram respondidas por pessoas com faixa etária de 18 a 30 anos de idade, $28 \%$ de 31 a 45 anos, $5 \%$ de 46 a 60 anos. Já com relação ao sexo, $57 \%$ foram do sexo feminino e $43 \%$ dos entrevistados, do sexo masculino.

Relacionada à quantidade de vezes que se utilizam os serviços da rede moteleira de Campo Mourão, anualmente, temos: 23\% dos entrevistados nunca utilizaram a rede moteleira da cidade, $12 \%$ utilizam pelo menos uma vez ao ano, $10 \%$ duas vezes, $7 \%$ três vezes e $48 \%$ afirmam utilizar desses serviços mais de quatro vezes ao ano. Vale ressaltar que o questionário foi enviado para várias pessoas tanto da cidade de Campo Mourão, quanto de diversas cidades vizinhas, o que
About cleanliness/ hygiene, there is an acceptable standard, it is obvious that any effort on the part of employees and owners is always positive, especially to avoid smell of smoke in the bed and bath linens. During the visit in motels M3 and M7, it was clear that this issue is very well addressed. Even if the employee, when cleaning the bedroom, realizes that the bed was not used all bedding is changed and washed as usually.

Food and drink are properly stored and follow the determinations of health monitoring service. Due to a weak demand and the high cost of service it is not viable for motels to maintain staff to prepare fresh meals.

An alternative to meet the needs of nourishment, is to establish a partnership between the motel and some restaurants in town, making available their menus with contact phone numbers in the bedrooms, offering the guests quality food at market prices.

On the item accessibility, the suggestion is that all the motels surveyed should keep at least an apartment within the ABNT standards for accessibility, because the presented structures show obstacles for a person with reduced mobility.

Another positive point of the motel chain is the overnight accommodation price, since it is more economical, and also has the rent-bythe-hour option and offers the same services as a hotel.

Regarding hosting an event in a motel, the cost for the customer is not feasible, because it is charged per couple. But it will also depend on how much the client wants and can spend to carry out this event. Furthermore, for the establishment it is feasible, because the profit is obtained mainly in the sale of drinks and food, as stated one of the owners of the visited motels.

Through the collected data, it is confirmed the first hypothesis of this research, in which the motels of the city of Campo Mourão are a good alternative for lodging, with a good attendance, proper sanitation and there is demand for hosting or attending an event in motels.

However, none of the researched motels have adequate space for holding events. In the future, this issue will be addressed given the reforms that are underway in existing motels, the recently opened motel and the one under construction. 
pode justificar os $23 \%$ de pessoas que nunca utilizaram os serviços da rede moteleira da cidade investigada.

No quesito tipo de acomodação, pode-se perceber que a maioria das pessoas optam pelos apartamentos, que totalizaram $66 \%$, e $34 \%$ utilizam-se de suíte, acreditando-se que o custo é levado em consideração quando da escolha da acomodação que será utilizada.

No que se refere às estruturas físicas serem acessíveis, como por exemplo: banheiro, barra de apoio, garagem e rampa de acesso para o atendimento aos portadores de necessidades especiais, $80 \%$ das pessoas afirmam que não existem padrões de acessibilidade e $20 \%$ afirma que sim.

Outro ponto muito discutido quando da utilização dos serviços, tantos em motéis quanto em hotéis, é quanto à limpeza do local, assim os questionários identificaram que das quarenta respostas, apenas $3 \%$ desses consideram a limpeza ótima e a sua maioria (65\%) considera a limpeza boa, já $25 \%$ considera regular e $7 \%$ ruim. Ficando claro que o cliente presta atenção e está cada vez mais exigente quando da higienização dos locais.

A sétima questão trata da utilização dos motéis para a realização de eventos, assim $52 \%$ das pessoas afirmaram que participariam de um evento organizado num motel, $25 \%$ talvez e $23 \%$ não frequentaria.

O último questionamento buscou identificar se as pessoas se hospedariam num motel, caso a rede hoteleira da cidade estivesse com a sua capacidade de hospedagem lotada, assim temos que $77 \%$ das pessoas se hospedariam sem problemas, $15 \%$ talvez e apenas $8 \%$ afirmou que não se hospedaria.

\section{CONSIDERAÇÕES FINAIS}

Avaliou-se, assim, que os motéis da cidade de Campo Mourão possuem facilidade de acesso principalmente por estarem localizados às margens de rodovias, o que facilita a entrada e saída das pessoas. No que diz respeito ao sigilo, característica básica de um motel, essa está sendo um pouco prejudicada devido ao crescimento da cidade com diversas empresas sendo instaladas próximas aos motéis.

Quanto à limpeza/higienização dos motéis, segue um padrão aceitável, é claro que todo e qualquer esforço, por parte dos funcionários e proprietários, é sempre
It is noteworthy that during this research a love motel was built in the city of Campo Mourão, it was inaugurated days before the conclusion of this article, because of this the new motel was not included as an object of study.

\section{REFERENCES}

ABNT, B. (2004, May 31). NBR 9050:2004 Accessibility buildings, furniture, spaces and urban facilities. $2^{a}$.

Alves, L. d. (2012). Geography and local authorities: relations between the hoteliers, the municipal government and the representative bodies in Campo Mourão. Master's dissertation presented to the Program of Graduate Studies in Geography, Department of Human Sciences Center of Geography, Literature and Arts of the State University of Maringa. Maringa, Paraná, Brazil.

Beni, M. C. (2004). Structural Analysis of Tourism (Vol. 10th Ed. Current). São Paulo, São Paulo, Brazil: Senac.

Borella, T. M. (2009). Feasibility study for moteleiro project. Retrieved June 28, 2013, from Federal University of Rio Grande do Sul: http://www.lume.ufrgs.br/ handle/10183/19204

Brazil, M. (1997). Decree no 36/97 of 25 September. Promulgated on 04 September 1997. Ratified on 10 September 1997. Retrieved August 20, 2013, from http:// www.oasrn.org/upload/apoio/legislacao/ pdf/tur3697.pdf

Brazil, M. (1997). Decree-Law 167/97 of 04 July. Promulgated on June 06, 1997. Retrieved September 17, 2013, from

http://www.oasrn.org/upload/apoio/ legislacao/pdf/tur16797.pdf

Brazil, M. (2011). Ordinance no 100 of 16 June, 2011. Retrieved September 13, 2013, from http://www.classificacao.turismo.gov.br/ MTUR-classificacao/mtursite/downloads/ portaria100_2011mtur.pdf

Campo Mourao, M. (2013). Contributors Report by Activity. Campo Mourao.

Carvalho, C. B. (2003). Social representation of Motels for Brazilians. Retrieved August 14 ,

2013, from http://bdm.bce.unb.br/ handle/10483/355

Giaretta, M. J. (2005). Hosting Alternative. In L. G. Trigo, A. P. Netto, M. A. Carvalho, \& P. d. Pires (Eds.), Regional and global analyzes of Brazilian tourism. Sao Paulo: Roca.

Gil, A. C. (2008). Methods and techniques of 
positivo, principalmente para se evitar cheiro de fumaça nas roupas de cama e banho. $\mathrm{Na}$ visita autorizada nos motéis M3 e M7, ficou claro que essa questão é muito bem orientada. Mesmo que o funcionário, durante a limpeza da UH, perceba que a cama não foi utilizada, todo o enxoval é trocado e a higienização ocorre normalmente.

Os alimentos e bebidas são armazenados de forma adequada e seguem as determinações da vigilância sanitária. Não sendo viável para os estabelecimentos manter um funcionário/ cozinheiro para o preparo de comidas frescas, devido à demanda por alimentação ser pequena e o custo, para manter o serviço, ser alto.

Uma alternativa para suprir a necessidade de alimentação dos usuários é a realização de parceria entre o motel e alguns restaurantes da cidade, colocando cardápios com telefones de contato nas UH's, oferecendo produtos de qualidade aos clientes e a preço de mercado.

No quesito acessibilidade, a sugestão é que todos os motéis pesquisados deveriam manter, pelo menos, um apartamento dentro das normas da ABNT para acessibilidade, pois a estrutura apresentada dificulta a locomoção das pessoas com mobilidade reduzida.

Outro ponto positivo da rede moteleira é em relação ao custo do pernoite, pois são mais econômicos, tem a opção do fracionamento por horas e oferecem os mesmos serviços de um hotel.

No que diz respeito à realização de evento no motel, o custo para o cliente é inviável, pois é cobrado por casal. Mas também vai depender de quanto o cliente pretende e pode gastar para a realização deste evento. Por outro lado, para o estabelecimento é viável, pois o lucro é obtido principalmente na comercialização das bebidas e alimentos, como afirmou um dos proprietários dos motéis visitados.

Mediante os dados coletados, confirmase a primeira hipótese levantada no início desta pesquisa, onde os motéis da cidade de Campo Mourão são opções vantajosas para hospedagem, possuem um bom atendimento, higienização correta e existe demanda para a realização ou participação de evento.

Porém, os motéis investigados não possuem espaço adequado para a realização de eventos. Futuramente, essa necessidade será suprida, visto as reformas que estão em andamento, ao motel recém-inaugurado e ao que está em construção. social research (6a ed.). Sao Paulo, Sao Paulo, Brazil: Atlas.

IBGE (2013). Campo Mourao Summary Information. Retrieved July 02 , 2013, from http://www.ibge. gov.br/cidadesat/xtras/temas. php?codmun $=410430 \&$ idtema $=16 \& \mathrm{~s}$ earch=Paraná|Campo Mourao | Summary of Information

Meirelles, G. F. (1999). Everything about events. Sao Paulo, Sao Paulo, Brazil: Editora STS.

SEBRAE, B. o. ([s.d]). Technical Motel. Retrieved August 20, 2013, from http:// www2.ms.sebrae.com.br/uploads/UAI/ fichastecnicas/motel.pdf

SENAC, N. (2011). Organization of social events ( $1^{a}$ ed). Curitiba, Parana, Brazil: Senac/Diret.

Souza, E. G. (2012, December). Considerations Motels as the Attitude Corporate legal system, year IV, n.1, p. 52-61 ten. 2012. Magazine Scientific SOPHIA - School AVANTIS / BC, Year IV $\left(1^{\mathrm{a}}\right)$, 52-61.

Walker, J. R. (2002). Introduction to hospitality. (G. E. Verçosa Son, Trans.) Sao Paulo, Sao Paulo, Brazil: Manole. 
Vale ressaltar que durante a realização desta pesquisa foi construído um motel na cidade de Campo Mourão, porém o mesmo foi inaugurado dias antes da conclusão deste artigo, o que inviabilizou a inclusão deste como objeto de estudo.

\section{REFERÊNCIAS}

ABNT, A. (31 de Maio de 2004). NBR 9050:2004 - Acessibilidade a edificações, mobiliários, espaços e equipamentos urbanos. $2^{a}$.

Alves, L. d. (2012). Geografia e poder local: relações entre os hoteleiros, o poder público municipal e as entidades representativas em Campo Mourão. Dissertação de mestrado apresentada ao Programa de Pós-Graduação em Geografia do Departamento de Geografia do Centro de Ciências Humanas, Letras e Artes da Universidade Estadual de Maringá. Maringá, Paraná, Brasil.

Beni, M. C. (2004). Análise Estrutural do Turismo (Vol. 10a Ed. Atual). São Paulo: Senac.

Borella, T. M. (2009). Estudo de viabilidade para projeto moteleiro. Acesso em 28 de Junho de 2013, disponível em Universidade Federal do Rio Grande do Sul: http://www. lume.ufrgs.br/handle/10183/19204

Brasil, M. (1997). Decreto Regulamentar no 36/97 de 25 de Setembro. Promulgado em 04 de setembro de 1997. Referendado em 10 de setembro de 1997. Acesso em 20 de Agosto de 2013, disponível em http:// www.oasrn.org/upload/apoio/legislacao/ pdf/tur3697.pdf

Brasil, M. (1997). Decreto-Lei no 167/97 de 04 de julho. Promulgado em 06 de junho de 1997. Referendado em 12 de junho de 1997. Acesso em 17 de Setembro de 2013, disponível em http://www.oasrn.org/ upload/apoio/legislacao/pdf/tur16797.pdf

Brasil, M. (2011). Portaria no 100, de 16 de Junho de 2011. Acesso em 13 de Setembro de

2013, disponível em http://www.classificacao. turismo.gov.br/MTURclassificacao/mtursite/downloads/portaria100_2011mtur.pdf

Campo Mourão, P. (2013). Relatório de Contribuintes por Atividade. Campo Mourão.

Carvalho, C. B. (2003). Representação Social dos Motéis para os brasileiros. Monografia apresentada ao Centro de Excelência em Turismo da Universidade de Brasília. Brasília, DF, Brasil.

Giaretta, M. J. (2005). Hospedagem Alternativa. In: L. G. Trigo, A. P. Netto, M.
A. Carvalho, \& P. d. Pires (Eds.), Análises regionais e globais do turismo brasileiro. São Paulo, São Paulo, Brasil: Roca.

Gil, A. C. (2008). Métodos e técnicas de pesquisa social (6a ed.). São Paulo, São Paulo, Brasil: Atlas.

IBGE, I. (2013). Campo Mourão Síntese de Informações. Acesso em 02 de Julho de 2013, disponível em http://www. ibge.gov.br/cidadesat/xtras/temas. php? codmun $=410430 \&$ idtema $=16 \& \mathrm{~s}$ earch=Paraná|Campo Mourão|Síntese das Informações

Meirelles, G. F. (1999). Tudo sobre eventos. São Paulo, São Paulo, Brasil: STS.

SEBRAE, S. B. ([s.d]). Ficha Técnica Motel. Acesso em 20 de Agosto de 2013, disponível em http://www2.ms.sebrae. com.br/uploads/UAI/fichastecnicas/motel. pdf

SENAC, S. (2011). Organização e cerimonial de eventos sociais ( $1^{\mathrm{a}}$ ed.). Curitiba, Paraná, Brasil: Senac/Diret.

Souza, E. G. (Dezembro de 2012). Considerações sobre Motéis como Atitude Empresarial no Ordenamento Jurídico. Revista Científica SOPHIA, Ano IV (n.1), 52-61.

Walker, J. R. (2002). Introdução à hospitalidade. (E. G. Verçosa Filho, Trad.) Barueri, São Paulo, Brasil: Manole. 
Tabela 1 - Resultado observação cliente oculto

\begin{tabular}{lcc|c|c|c|c}
\hline Item & M1 & M2 & M3 & M4 & M5 & M7 \\
\hline 1) Atendimento & Ruim & Bom & Ótimo & Bom & Bom & Ótimo \\
2) Acessibilidade & Não & Não & Sim & Não & Sim & Não \\
3) Limpeza & Ruim & Bom & Ótimo & Ótimo & Bom & Ótimo \\
4) Equipamentos & Ruim & Bom & Bom & Ótimo & Ótimo & Bom \\
5) Alimentos & Ruim & Bom & Bom & Bom & Regular & Bom \\
6) Bebidas & Regular & Bom & Ótimo & Bom & Bom & Ótimo \\
\hline
\end{tabular}

Fonte: Autora, novembro de 2013 a agosto de 2014.

NOTA

1 Informações obtidas através de contato telefônico no início da pesquisa em 2013.

\section{APPENDIX}

Table 1 - Results of mystery shopper observation

\begin{tabular}{lccccccc}
\hline Item & M1 & M2 & M3 & M4 & M5 & M7 \\
\hline 1) Service Quality & Bad & Good & Excellent & Good & Good & Excellent \\
2) Accessibility & No & No & Yes & No & Yes & No \\
3) Cleanliness & Poor & Good & Excellent Excellent & Good & Excellent \\
4) Equipment & Poor & Good & Good & Excellent & Excelent & Good \\
5) Food & Poor & Good & Good & Good & Fair & Good \\
6) Beverages & Fair & Good & Excellent & Good & Good & Excellent
\end{tabular}

Source: Author, November 2013 to August 2014.

ENDNOTES

1 Information obtained by telephone at baseline in 2013 . 